\title{
溶接鋼の高温割れについで
}

\author{
益本功** 今井萧敬***
}

\section{On the Hot Cracking in Weld Metal*}

by Isao Masumoto** and Kaneyuki Imai***

\begin{abstract}
The effects of carbon, manganese, phosphor, sulphur and nickel on the hot cracking and micro segregation of weld metal were examined in submerged arc welding process using the electron probe microanalyser.

Based on the results of this study, the following conclusions are drawn:

1) Segregation of sulphur concentration is larger in weld metal containing more than $0.1 \% \mathrm{C}$ than one containing less than $0.1 \% \mathrm{C}$, and manganese behaves in the same manner as sulphur.

2) Micro segregation or hot cracking of weld metal containing nickel is strongly influenced by the phase solidified as primary crystal in Fe-Ni diagram. Moreover newly solidified phase by peritectic reaction: $\quad \delta+$ Liquid $\rightarrow r$ promotes segregation of sulphur and phosphor concentration.

3) Prime cause of hot cracking in weld metal is sulphur segregation, and the effect of phosphor can be considered as far less than that of sulphur.
\end{abstract}

\section{1. 緒言}

著者らは低温用低ニッケル合金鋼のガス被包アーク溶 接に関する研究において二ッケルを $2.5 \%$ 以上含有する 溶接鍋の高温割れにおよぼすいおうの影響について報告 したととがある ${ }^{1)}$ この研究に扔いて，共存するりんの 影響についてはじゅう分明らかにすることができなかっ た.

そてで本研究では溶接入熱が大きく, 冷却速度の遅い サブマージアーク溶接を使用して, 溶接銅の高温割れに およばす主としてりんの影響を明らかにするために，板 厚 25〜32 $\mathrm{mm}$ の鋼板にV溝をほり溶接実験を行なっ た.すなわち、りんおよびニッケルを種々の割合で含む フラックスと $2.5 \% ， 3.5 \%$ 极よび $9 \%$ \%ケル鋼母材等 とを組合せて溶接し，溶接鋼の高温㓶れにおよばすニッ ケル，炭素,りん括よびいおうの影響について調べた。

そしてサブマージアーク溶接の場合にはニッヶルを含 有した溶接鋼の高温割れにりんがある程度影響すること を梕めたが， $0.10 \%$ 以下りん含显の場合には高温割れ 部分にもりんの偏析は認められなかった。しかし，本実 験ではいおう含量を0.007〜0.009\%に押えたにも录かわ

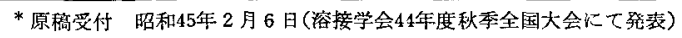

**正員·名古屋大学工学的 Member, Faculty of Engineering of Nagoya University

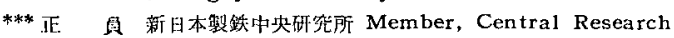
la boratories, Nippon Steel Corporation
らず，高温割れの部分にはいおうの著しい偏析が認られ た。また炭素含量が $0.12 \%$ 以上の溶着鋼は高温割れに敏 感であることを確めた。

てれらの結果から溶接鋼の高温割れにおよぼすりん， い扰うンニッケル执よび炭索の影㗽について治金学的考 察を行なった。

\section{2. 供 試 材 料}

供試鋼板は，溶着鋼の炭素合量および母材強度を変化 させるため，軟鋼，アルミキルド $\mathrm{Si}-\mathrm{Mn}$ 系鋼および高 張力釦板（板厚 $20 \sim 22 \mathrm{~mm}$ ) を使用し, 溶着鋼のニッ ケル含量を変化させるため，アルミキルド Si-Mn 系 銅, $2 \frac{1}{2} \% \mathrm{Ni}, 3 \frac{1}{2} \% \mathrm{Ni}$ および $9 \% \mathrm{Ni}$ 鋼板（板厚 $25 \sim$ $32 \mathrm{~mm}$ ) を使用した。 それらの化学組成を Table 1 に まとめて示す。

供試溶接材料としては Table 1 亿併記したけい菜お よびマンガン含量を異にする3 種類の溶接ワイヤーなら びに Table 2 に示す 2 種類のフラックスを使用した。

\section{3. 実 験 方 法}

溶接鋼の高温割れにおよぼす炭素の影響を調べるた めに Table 2 に示す溶融型のフラックスを用い，V满

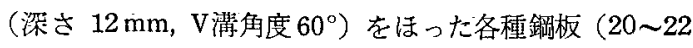
$\times 280 \times 500 \mathrm{~mm})$ 上にサブマージアーク溶接でビード溶 
Table 1 Chemical compositions of base metals and welding wires

\begin{tabular}{|c|c|c|c|c|c|c|c|c|c|c|}
\hline \multirow{2}{*}{\multicolumn{2}{|c|}{ Materials }} & \multirow{2}{*}{$\begin{array}{c}\text { Plate } \\
\text { thickness or } \\
\text { diameter, } \\
\text { mm }\end{array}$} & \multicolumn{8}{|c|}{ Elements, wt. $\%$} \\
\hline & & & C & $\mathrm{Si}$ & $\mathbf{M n}$ & $\mathrm{P}$ & $\mathrm{s}$ & $\mathrm{Ni}$ & $\mathrm{Nb}$ & $\mathrm{V}$ \\
\hline \multirow{2}{*}{\multicolumn{2}{|c|}{$\begin{array}{l}\text { SM } 41 \text { B } \\
\text { FTW } 52\end{array}$}} & \multirow{2}{*}{20} & 0.16 & 0.03 & 1.10 & 0.011 & 0.014 & - & - & - \\
\hline & & & 0.16 & 0.31 & 1.30 & 0.010 & 0.009 & - & - & - \\
\hline \multirow{2}{*}{\multicolumn{2}{|c|}{$-\quad X-65$}} & \multirow{2}{*}{22} & 0.19 & 0.42 & 1.33 & 0.014 & 0.004 & - & 0.06 & 一 \\
\hline & & & 0.20 & 0.42 & 1.35 & 0.010 & 0.005 & - & - & 0.111 \\
\hline \multicolumn{2}{|c|}{$\begin{array}{c}\text { Al killed Si-Mn } \\
\text { steel }\end{array}$} & 20 and 32 & 0.10 & 0.23 & 1.20 & 0.013 & 0.003 & 0.04 & - & $\omega$ \\
\hline \multirow{2}{*}{\multicolumn{2}{|c|}{$\begin{array}{l}21 / 2 \% \mathrm{Ni} \text { steel } \\
31 / 2 \% \mathrm{Ni} \text { s teel }\end{array}$}} & \multirow{2}{*}{32} & 0.09 & 0.13 & 0.54 & 0.006 & 0.005 & 1.98 & 一 & 一 \\
\hline & & & 0.06 & 0.22 & 0.53 & 0.006 & 0.005 & 3.22 & - & 一 \\
\hline \multicolumn{2}{|c|}{$9 \% \mathrm{Ni}$ steel } & 25 & 0.07 & 0.23 & 0.34 & 0.012 & 0.003 & 9.21 & - & - \\
\hline \multirow{3}{*}{$\begin{array}{l}\text { Electrode } \\
\text { wire }\end{array}$} & W10 & \multirow{3}{*}{$4.8 \phi$} & 0.12 & 0.03 & 1.95 & 0.010 & 0.006 & & \multirow{3}{*}{-} & \\
\hline & W20 & & 0.06 & 0.005 & 0.55 & 0.019 & 0.010 & & & \\
\hline & W30 & & 0.09 & 0.10 & 1.00 & 0.010 & 0.006 & & & \\
\hline
\end{tabular}

Table 2 Chemical compositions of welding fluxes

\begin{tabular}{|c|c|c|c|c|c|c|c|c|c|}
\hline Welding flux & $\mathrm{SiO}_{2}$ & $\mathrm{MnO}$ & $\mathrm{CaO}$ & $\mathrm{Al}_{2} \mathrm{O}_{3}$ & $\mathrm{TiO}_{2}$ & $\mathrm{MgO}$ & $\mathrm{CaF}_{2}$ & $\mathrm{Fe}-\mathrm{Mn}$ & Note \\
\hline 1 & 22.4 & - & 9.8 & 10 & 5 & 26 & 20 & 7 & Bonded flux \\
\hline 2 & 38.4 & 13.0 & 24 & 4 & 6 & 7.5 & 7.0 & $\ldots$ & Fused flux \\
\hline
\end{tabular}

着を行なった。溶接条件は $600 \mathrm{~A}, 34 \mathrm{~V}, 45 \mathrm{~cm} / \mathrm{min}$ で ある。

また溶接龬の高温割れにおよぼすニッケルとりんの影 響を調べるためには，Table 2 に示すボンドタイプの基 本フラックスにりんおよびニッケルを種々の割合で配合 し，とのフラックスを用いV溝（深さ $10 \mathrm{~mm}, \mathrm{~V}$ 满角度 $\left.60^{\circ}\right)$ をほった各種鋼板 $(25 \sim 32 \times 150 \times 450 \mathrm{~mm})$ 王に サブマージアーク溶接でビード溶着を行なった，との封 の溶接条件は $800 \mathrm{~A}, 30 \mathrm{~V}, 30 \mathrm{~cm} / \mathrm{min}$ である. 溶接試 験材は，溶接終了後，ビード外観の観祭，X線透過試験 を行ない，さらにナイタール應食した溶着鋼のマクロお よびミクロ組織を観察し，溶着錩の制れの有整について 調べた。な打溶着鋼の微視的嶩度分布を調べるためにX 線マイクロアナライザーを使用し，高温制れ破面の微察 に走查型電子顕微鏡を使用した。

\section{4 、高温割れにおよぼす溶着鋼の 化学組成の影響}

\section{1 溶着鋼の高温割れにおよぼす炭素の影響}

Fig. 1 は SM 41 B, FTW 52 および X-65 の銅板を 種々熱処理して，母材強度を变化させて溶接した場合の 溶着鋼の高温割れにおよばす炭素の影響を示している。 同図によれば，溶着鋼の高温割れは倣素含量 $0.12 \%$ 以上 で, 発生し始めるが，母材の強度の影響は認められな い.そこで溶着鋼の高温割的付近あるいは最終凝固部付 近の微視的濃度分布をX線マイクロアナライザーを使っ

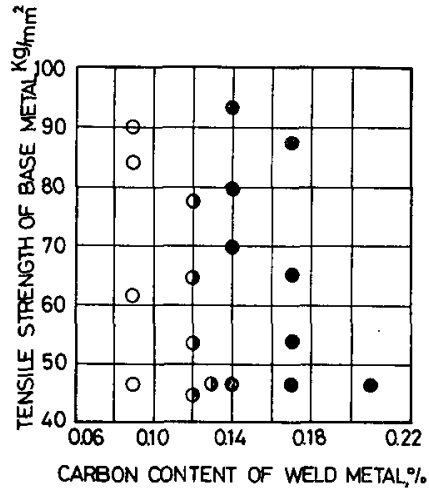

Fig. 1 Effect of carbon content of weld metal and strength of base metal on hot cracking note:

$$
\begin{aligned}
& \text { crack } \\
& \text { crater crack } \\
& \text { no crack }
\end{aligned}
$$

て調べた，これらの測定に用いた溶着鍽の化学組成を Table 3 に示した.

Fig. 2 は制れを発生しなかった溶着鋼 W $1(0.083 \%$ C, $1.13 \% \mathrm{Mn}, 0.017 \% \mathrm{P}, 0.027 \% \mathrm{~S})$ の最終凝固部付 近を中心にしてりん，いおう扔よびマンガン濃度分布を 測定した結果の一部を示す．同図は特に炭素含量が少な い場合であるが後述の炭素含量が多い Fig. 3 亿比べ， マンガン括よびいおうの偏析の程度は小さく，マンガン のピークのところではいおうの值はとくに低くなってい ろ. 
'Table 3 Chemical compositions of weld metals

\begin{tabular}{|c|c|c|c|c|c|c|c|}
\hline \multirow{2}{*}{ Base metal } & \multirow{2}{*}{ Weld metal } & \multicolumn{6}{|c|}{ Elements, wt. $\%$} \\
\hline & & C & $\mathrm{Si}$ & $\mathrm{Mn}$ & $\mathrm{P}$ & $\mathbf{S}$ & $\mathrm{Nb}$ \\
\hline$F L T-2 B$ & W 1 & 0.083 & 0.35 & 1.13 & 0.017 & 0.027 & - \\
\hline \multirow{3}{*}{$X-65$} & W 2 & 0.142 & 0.45 & 1.26 & 0.010 & 0.025 & - \\
\hline & W 3 & 0.147 & 0.43 & 1.47 & 0.018 & 0.011 & 0.014 \\
\hline & W 4 & 0.140 & 0.42 & 1.40 & 0.016 & 0.010 & 0.012 \\
\hline
\end{tabular}

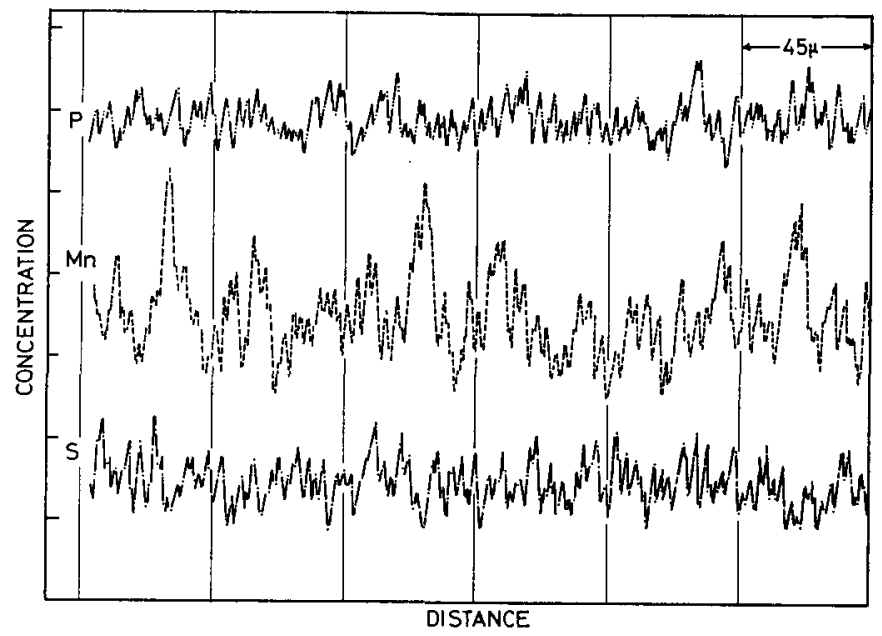

Fig. 2 Distribution of manganese, sulphur and phosphor concentration in weld metal, W1

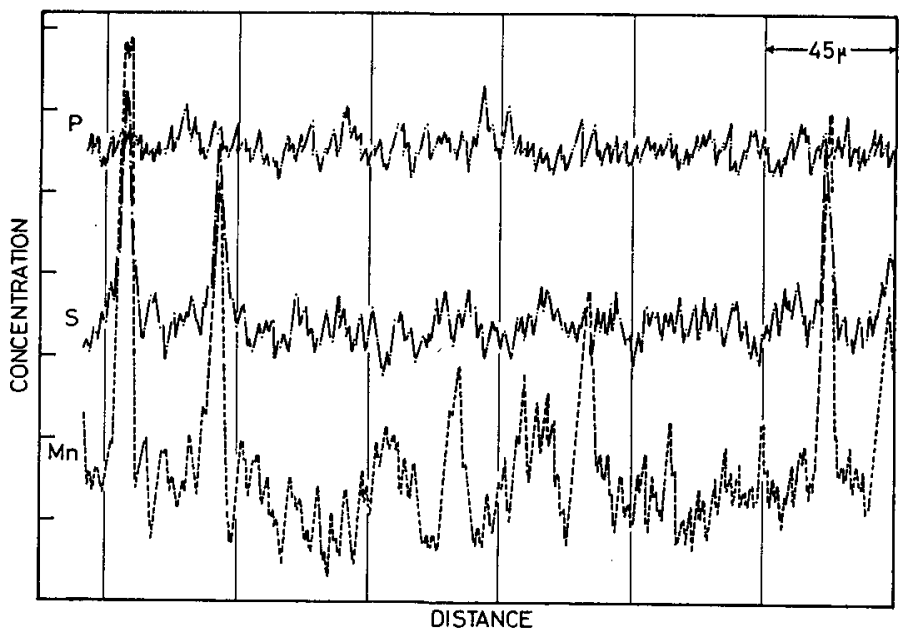

Fig. 3 Distribution of manganese, sulphur and phosphor concentration in weld metal, W2

Fig. 3 は割れが発生しなかった溶着鋼 W $2(0.14 \%$ C, $1.26 \% \mathrm{Mn}, 0.010 \% \mathrm{P}, 0.026 \% \mathrm{~S})$ の最終凝固部付近を 中心に測定した結果の一部を示す，同図によると，Fig. 2 の場合といおう含量はほとんど変らないのにかかわら ず，いおうの微視的濃度分布は，Fig. 2 の炭菜の低い場 合にくらべ著しく，濃度のピークが数個所す認められ
る.またマンガンといおうが同じ個所で著しい濃度上昇 を示している点は Fig. 2 の場合と晎なる。りんについ てはいおうおよびマンガンのような際立った変動は認め られない。

Fig. 2 上 Fig. 3 Kおけるい括うの微視的濃度の差は Fe-C (Fig. 4) および Fe-S (Fig. 5) 二元状態図 $\left.\right|^{2}$ の频 


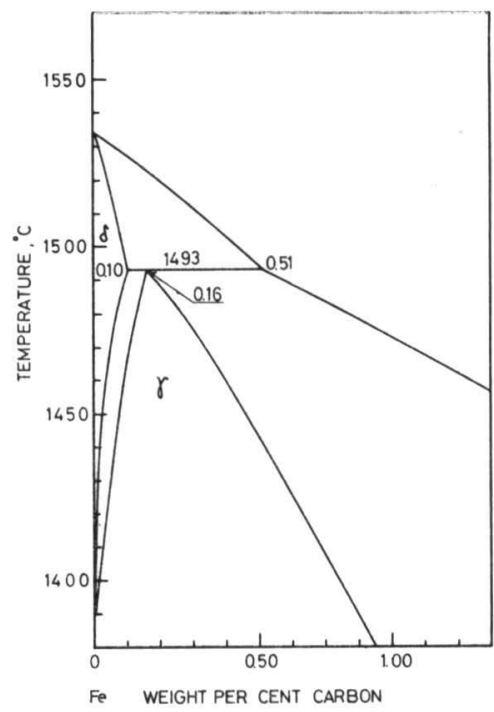

Fig. 4 Constitutional diagram of peritectic reaction of Fe-C system

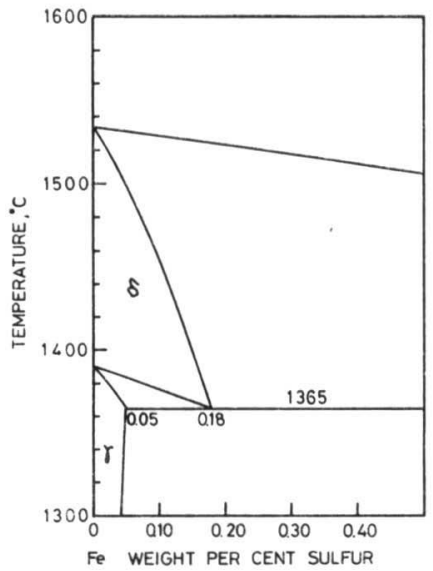

Fig. 5 Sulphur solubility of $\delta$ and $\gamma$ iron

固過程において晶出する相の相違にもとずくものと思わ れる. すなわち $0.083 \% \mathrm{C}$ の溶着鋼では初晶として $\delta$ 相 を晶出し， $\delta$ 相におけるいおうの固溶度は Fig. 5 に示 すごとく $0.18 \%$ である.しかし $0.142 \% \mathrm{C}$ の溶着鋼の 場合は，包晶反応により $\delta$ 相を核として $\gamma$ 相で包まれな がら凝固が進行する. しかも $\%$ \%, $\delta$ 相の固溶度にくらべて著しく低い。したがって $\delta$ 相の最大炭素固溶度 $0.1 \%$ 以上では包晶反応により颣 固過程で粒界に $r$ 相が晶出するため, その粒界には $\delta$ 相 に比べ多量のいおうが偏析する可能性がある.

Fig. 6 および 7 は高温割れをおこした溶着鋼の割れ 近傍の微視的濃度分布を示す. Fig. 6 は溶着鋼 W 3 $(0.147 \% \mathrm{C}, 1.47 \% \mathrm{Mn}, 0.018 \% \mathrm{P}, 0.011 \% \mathrm{~S})$ の高温

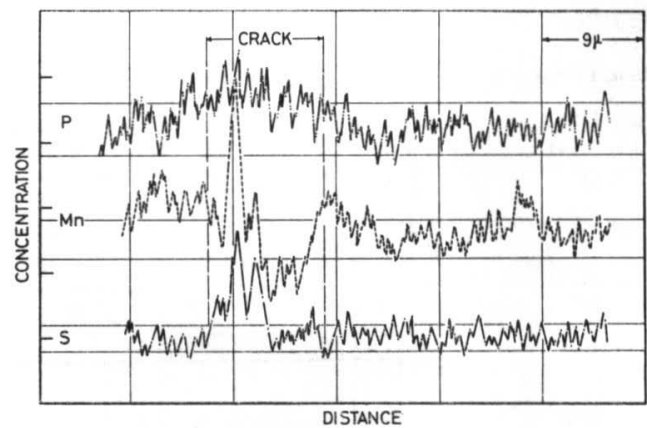

Fig. 6 Crack crossed distribution of manganese, sulphur and phosphor concentration in weld metal, W3

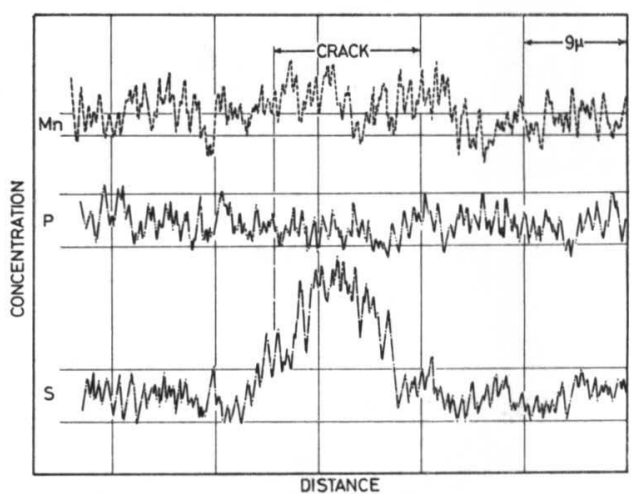

Fig. 7 Crack crossed distribution of manganese, sulphur and phosphor concentration in weld metal, W4

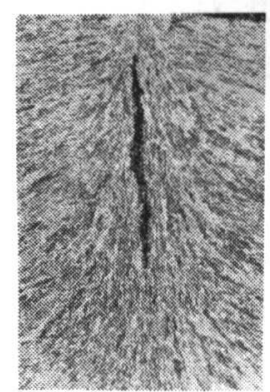
a) $\times 10 \times 1 / 2$
b) $\times 400 \times 1 / 2$

Photo. 1 Macrostructure showing hot cracking of weld metal (W3) and enlarged scanning location by X-ray microanalyzer

割れ近傍であり, X 線マイクロアナライザー走査位置お よびマクロ組織を Photo. 1 に示す.

Fig. 6 によると, いおう含量はかなり低いのにかかわ らず溶着鋼は包晶反応を経て凝固することが考えられ， 割れ部分ではマンガンおよびいおうのいちじるしい濃度 
上昇が認められる.しかもりん濃度も割れていない部分 にくらべてわずか高くなっている.

Fig. 7 は溶着鋼 W $4(0.140 \%$ C, $1.40 \% \mathrm{Mn}, 0.016$ $\% \mathrm{P}, 0.010 \% \mathrm{~S})$ の高温割れ近傍であり, X線マイクロ アナライザー走查位置および溶着鋼の割れ付近のマクロ 組織を Photo. 2 に示す. Fig. 7 亿捄いてむ Fig. 6 と

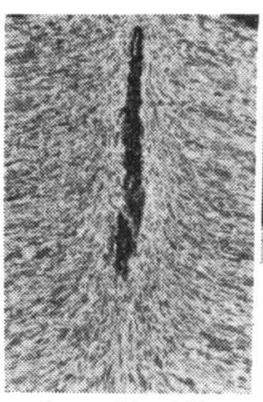

a) $\times 10 \times 1 / 2$

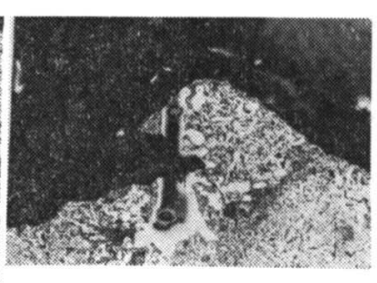

b) $\times 400 \times 1 / 2$
Photo. 2 Macrostructure showing hot cracking of weld metal (W4) and enlarged scanning location by $\mathrm{X}$-ray microanalyzer

全く同様でいおうの濃度は割れ部分で著しい上昇を示し ている. そてでいおう偏析部分の点分析を行なった結 果, 割れていない部分のいおう濃度にくらべ，8倍に達 しており， $r$ 相のい抢う固溶度をはるかにてえて偏析し ているととを認めた．乙れが高温割れの原因と想像され る.しかもマンガンは割れ部分であまり濃度上昇が認め られず, この付近の硫化物は FeS を主としたもののよ うである.あっとも他の個所での X 線マイクロアナライ ザーの結果では, たとえば Fig. 6 のように割れ部分で いおうとともにマンガンの著しい濃工上昇が認められる 場合ああった. 本実験に扔いてあ割れの個所ではりん濃 度に目立った変動は認められなかった。

\section{2 ニッケル含量と偏析との関係}

Fig. 8 はサブマージアーク溶接による溶着鋼の高温割 れにおよぼすりんとニッケルの影響を示している.なお これらの溶着鋼のいおう含量は 0.007 ない $0.009 \%$ で

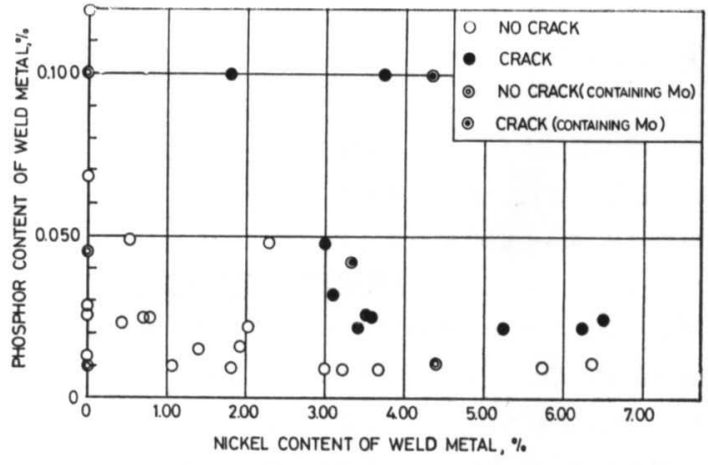

Fig. 8 Effect of nickel and phosphor contents on the hot cracking in weld metal

ほぼ一定であり, 炭素含量は 0.05 ないし $0.09 \%$ の範囲 である. 同図によると, ニッケルを含まない溶着鋼では りんを $0.12 \%$ 含有してあ高温割れを発生していない. と ころがニッケルを $1.8 \%$ 含む溶着鋼ではりんを $0.1 \%$ む 含むと割れが発生し, ニッケル含量 $3.0 \%$ 以上になれ

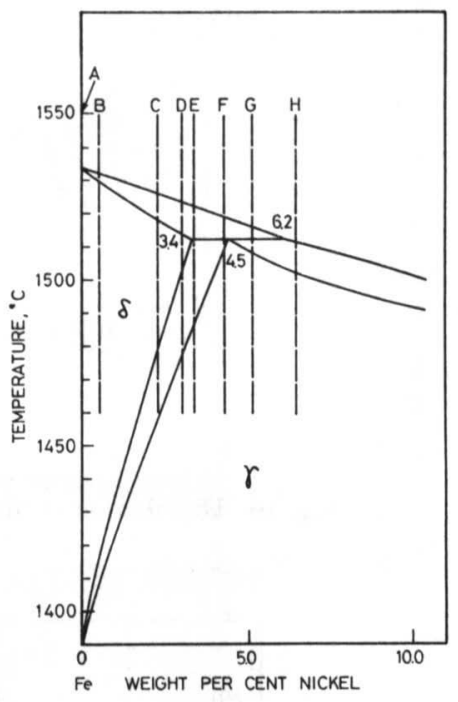

Fig. 9 Constitutional diagram of peritectic reaction of $\mathrm{Fe}-\mathrm{Ni}$ system

Table 4 Chemical compositions of weld metals and effect on hot cracking

\begin{tabular}{|c|c|c|c|c|c|c|c|}
\hline \multirow{2}{*}{ Weld metal } & \multicolumn{6}{|c|}{ Element, \% } & \multirow{2}{*}{$\begin{array}{l}\text { Occurrence of } \\
\text { hot cracking }\end{array}$} \\
\hline & $\mathrm{C}$ & $\mathrm{Si}$ & $\mathrm{Mn}$ & $P$ & $\mathrm{~s}$ & $\mathrm{Ni}$ & \\
\hline A & 0.085 & 0.26 & 1.33 & 0.100 & 0.007 & 0.03 & \\
\hline B & 0.077 & 0.19 & 1.18 & 0.049 & 0.007 & 0.55 & NO \\
\hline $\mathrm{C}$ & 0.083 & 0.22 & 1.30 & 0.048 & 0.007 & 2.31 & \\
\hline $\mathrm{D}$ & 0.058 & 0.19 & 1.09 & 0.048 & 0.009 & 3.02 & \\
\hline $\mathrm{E}$ & 0.063 & 0.21 & 1.00 & 0.022 & 0.009 & 3.42 & \\
\hline $\mathrm{F}$ & 0.074 & 0.21 & 1.07 & 0.100 & 0.008 & 4.36 & YES \\
\hline G & 0.059 & 0.20 & 1.00 & 0.022 & 0.007 & 5.21 & \\
\hline $\mathrm{H}$ & 0.059 & 0.19 & 0.90 & 0.025 & 0.008 & 6.51 & \\
\hline
\end{tabular}


ば，りん含量 $0.02 \%$ 以上で高温割れがすべての場合に発 生した。すなわちニッケル含量が煘くなれば，りん屯 高温割れに寄与するように見られる。しかしての推論は 後に述べるごとく正しくない. Table 4 に示す二ッケル およびりん含量の異なる8 種類の溶着鋼について割れな い場合は最終凝固部付近あるいは高温割れ近傍のニッケ ル，りん，マンガン执よびいおうの微視的濃度分有を $\mathrm{X}$ 線マイクロアナライザーにより調べた。これらの測定に 用いた試料のニッケル含量を $\mathrm{Fe}-\mathrm{Ni}$ 二元状態図に図示 して Fig. 9 に示す.

溶着鋼 A $(1.33 \% \mathrm{Mn}, 0.10 \% \mathrm{P}, 0.007 \% \mathrm{~S}, 0.03 \%$ $\mathrm{Ni}$ )の最終凝固部付近をX線マイクロアナライザーで分 析した結果の一部を Fig. 10 に示し, 溶着鋼のマクロ 組織を Photo. 3 (a) に示す. 同図に示すように二ッケ
ルをほとえど含まない場合にはりん念目が0.10\%でも， 微視的濃度分布にはりんの著しい偏析が热められない。 またマンガンおよびいおうの微視的濃度分布す，後述す るほど目立った偏析を示していない。

溶着鋼 B $(1.18 \% \mathrm{Mn}, 0.049 \% \mathrm{P}, 0.007 \% \mathrm{~S}, 0.55 \%$ $\mathrm{Ni})$ 执よび C (1.30\% Mn, $0.048 \% \mathrm{P}, 0.007 \% \mathrm{~S}, 2.31$ $\% \mathrm{Ni}$ ) の最終凝固部付近の铅視的濃度分布も. Fig. 10 の. 場合とほとんど同じで，ニッケル，りん，マンガンおよ びいおうに著しい偏析は認められなかった．溶着鋼Cの 場合を Fig. 11. に示す.すなわち Fig. 9 に示すように ニッケル含量が少なく，完全に $\delta$ 相一相で疑固すると思 われる籁围では，ミク口偏析は少ないようである。これ らのマクロ組織 Photo. 3 (b), (c) 飞示す.

Fig. 12 は $\delta$ 相の最大ニッケル固溶度 $3.4 \%$ すなわち

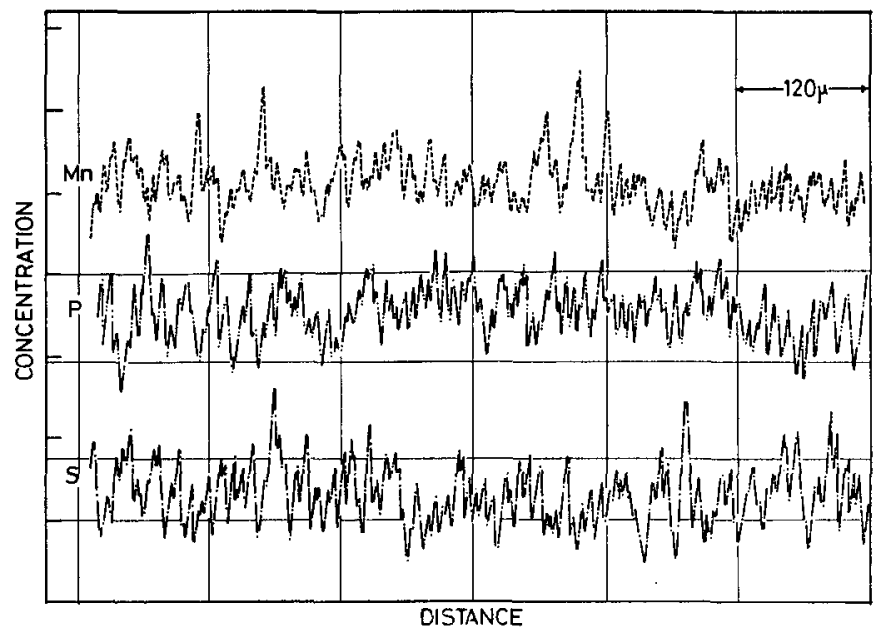

Fig. 10 Distribution of manganese, sulphur and phosphor concentration in weld metal, $\mathrm{A}(0.03 \% \mathrm{Ni})$

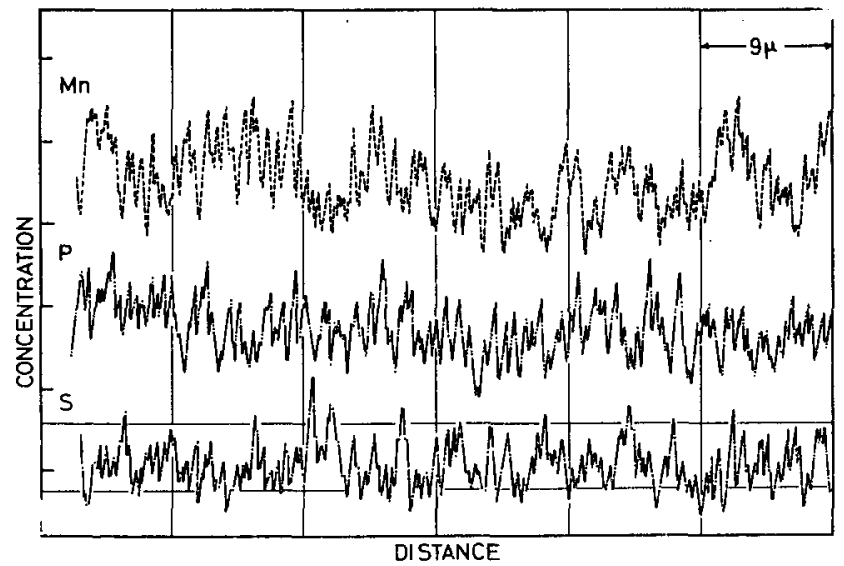

Fig. 11 Distribution of manganese, sulphur and phosphor concentration in weld metal, $\mathrm{C}(2.31 \% \mathrm{Ni})$ 


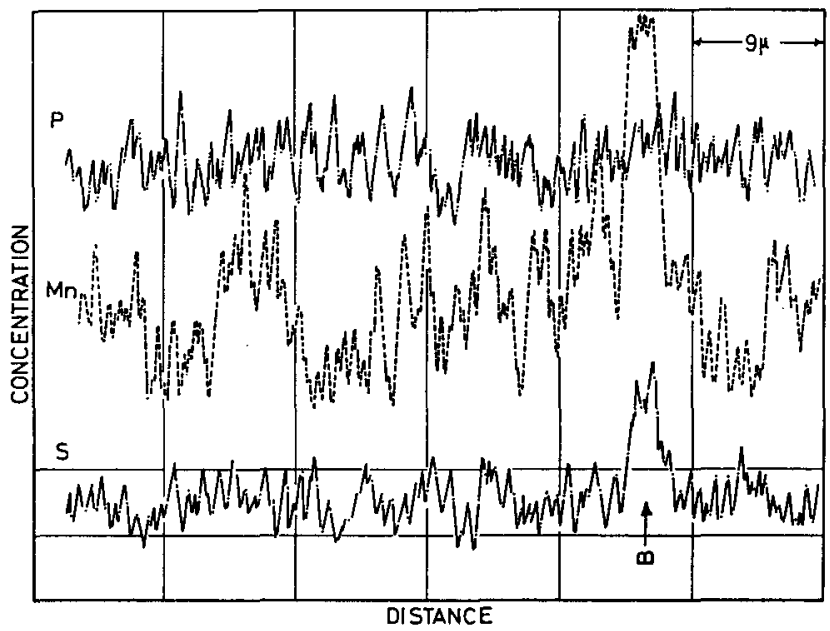

Fig. 12 Distribution of mangancse, sulphur and phosphor concentration in weld metal, $\mathrm{D}(3.02 \% \mathrm{Ni})$

Remark: $\mathrm{B}$; grain boundary

包晶反応開始の莀度飞近い溶着鋼 D $(1.09 \% \mathrm{Mn}, 0.048$ $\% \mathrm{P}, 0.009 \% \mathrm{~S}, 3.02 \% \mathrm{Ni})$ の最終凝固部付近の粒界を 横切ってX線マイクロアナライザーで走查した結果の一 部を示し，マクロ組織をPhoto. 3(d) に示している.

Fig. 12 によると，いおうの偏析はオーステナイト粒界 で扔てって扔り，ニッケル $2.31 \%$ 以下の完全に $\delta$ 相で楚 固する上記 3 種の場合にくらべて，いおうの莀度上曻が 顕著である、マンガンの濃度む，い㧍うの濃度上昇に対 応して著しく高くなっている．またマンガンは粒内です 濃度の変動が認められる。な招点分析の結果，いおうの 粒界に招ける浱縮度は平均濃度の9倍であり，マンガン については3倍であった。

Fig. 13 は Fig. 9 亿示すでとく，包昆反応をわずか 飞伴う溶着銅 $\mathrm{E}(1.00 \% \mathrm{Mn}, 0.022 \% \mathrm{P}, 0.009 \% \mathrm{~S}, 3.42$ $\% \mathrm{Ni}$ ) の高温㓶れ近傍の微視的濃度分布を示し，割れを 含む最終凝固部付近のマクロ組織を Photo. 3（e）に示 す。同図によると，割れ部分におけるいおうおよびマン ガンの濃度は割れていない部分の濃度と比較すると，著 しく高くなっている。い括う扰よびマンガンの点分析に よると，割れた部分のいおう濃度は割れていない部分の 濃度にくらべて 5 10倍であり，マンガン濃度は 4 倍で あった。一方同図はニッケルおよびりん濃度が割れてい ない部分にくらべて低下しているてとを示す。

溶着錩 $\mathrm{F}(1.07 \% \mathrm{Mn}, 0.100 \% \mathrm{P}, 0.008 \% \mathrm{~S}, 4.36 \%$ Ni）は Fig. 9 亿示すように包晶反応を生ずる範囲で特 にりんを高くした場合であるが，乙の場合には Fig. 14 に示すでとく，割れ近傍でりんの㾫析が証められた。 た同図に見ら礼るごとく、りんの偏析の著しい所ではい おうの俯析は頙著でない，さらに同じ溶潜鐥について制

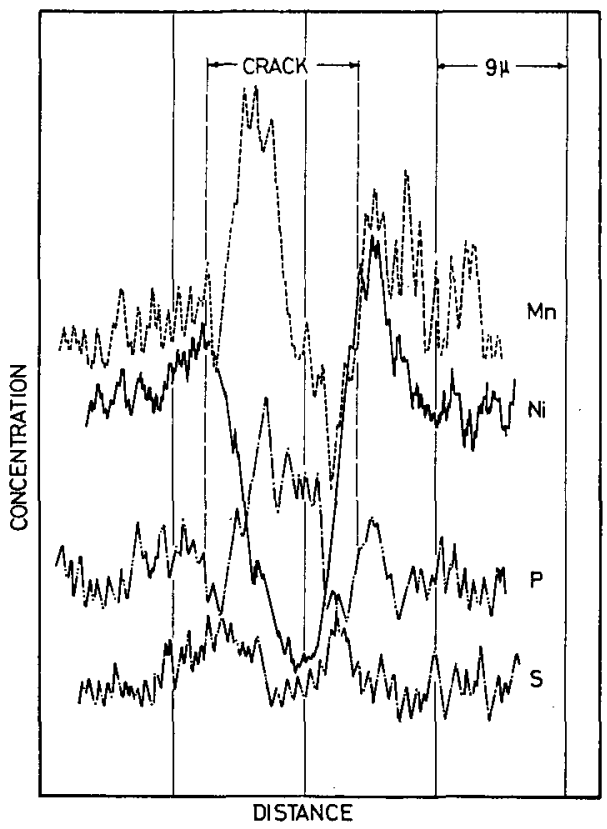

Fig. 13 Segregation of manganese and sulphur at a crack of weld metal, E $(3.42 \% \mathrm{Ni})$

れていない部分においても，りんのピークが認められ た.なおこの溶着銅の割れの他の部分 (Fig. 15) では これまでに述べたのと同様い招うの蕃しい偏析が認めら れ，この部分では逆にりんの偏析は認められなかった。 さらにりん浱度の高い敖れた部分の 2 個所でニッケル， マンガン，り九扰よ゙い掠うの四元素について点分析し た結果，マンガンは0.8〜0.9倍，り九は 4 15倍，いお う $2 \sim 5$ 倍, ニッケル0.6〜0.8倍であった。な溶着鋼 


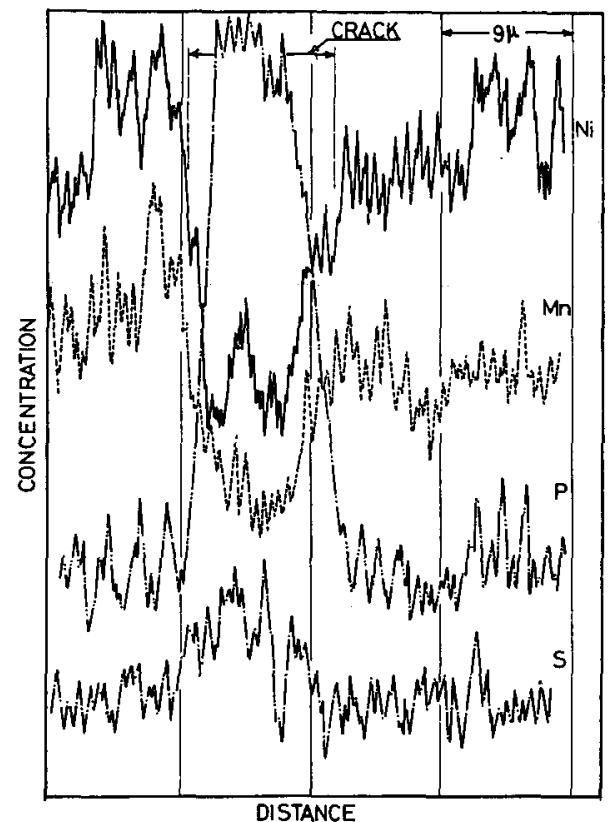

Fig. 14 Segregation of phosphor at a crack of weld metal, F $(4.36 \% \mathrm{Ni})$

のマクロ組織を Photo. 3 (f) に示す.

以上の実験結果加ら，ニッケルを含み，包晶反応によ り粒界に $\gamma$ 相を晶出しながら疑固する溶着鋼でりん含量 がいちじるしく高い場合にのみミク口偏析が認められる が，一般には，い抢うに比べ，最終凝固域あるいはオ一 ステナイト粒界での偏析傾向はずっと低いと考えら れる.すなわちニッケルを含まない極低炭素溶着鋼 $\mathrm{A}$ （Fig. 10）とニッケルを $4.36 \%$ 含む溶着鋼 F（Fig. 14

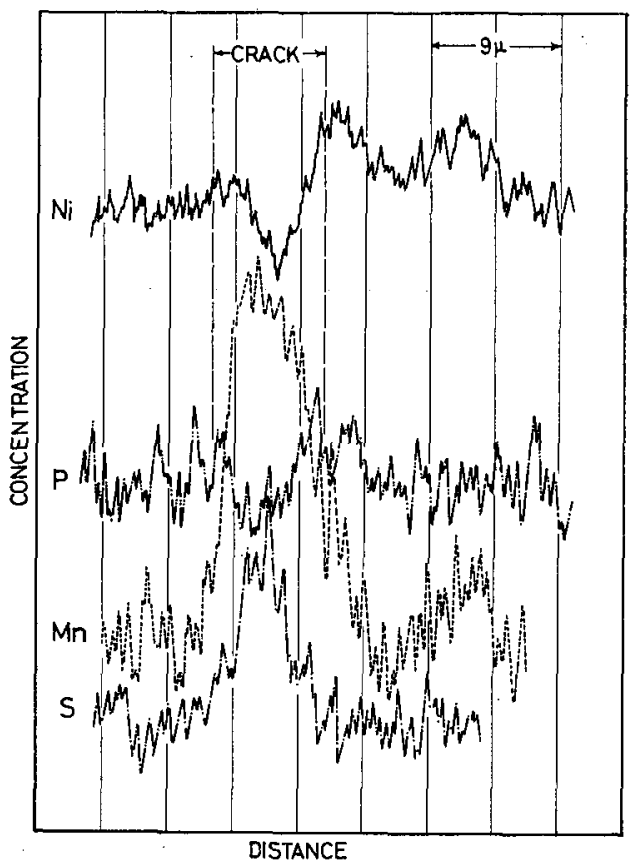

Fig. 16 Segregation of manganese and sulphur at a crack of weld metal, $\mathrm{G}(5.21 \% \mathrm{Ni})$

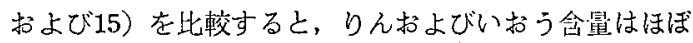
同じであるにすかかわらず，包䐉反応を伴う後者の方が 偏析ははるかに著しい。

Fig. 16 はさらに包晶反応により多量の 溶着鋼 $\mathrm{G}(1.00 \% \mathrm{Mn}, 0.022 \% \mathrm{P}, 0.007 \% \mathrm{~S}, 5.21 \% \mathrm{Ni})$ の割机近傍の微視的濃度分布を示す. 割れ近傍のマクロ 組織は Photo. 3(g) K示す. Fig. 16 によると，小さ

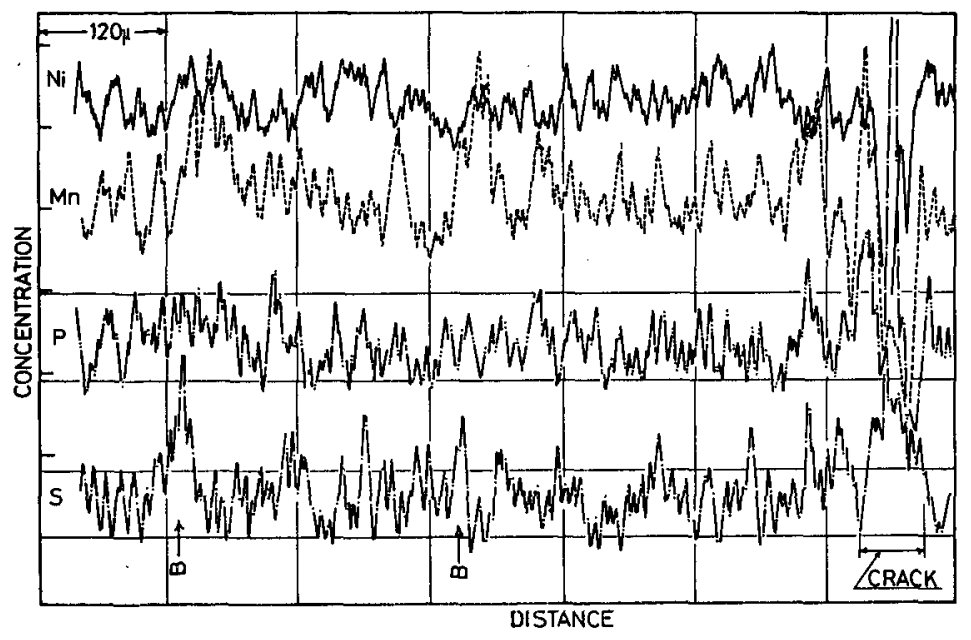

Fig. 15 Distribution of nickel, manganese, sulphur and phosphor concentration in weld metal, $\mathrm{F}(4.36 \% \mathrm{Ni})$

Remark: B; grain boundary 
な割れ部分における漏析が著しく高くなっているただ しりん含量は $0.02 \%$ 程度であるので偏析は認められな い.さらに割れ部分におけるいおうについて点分析した

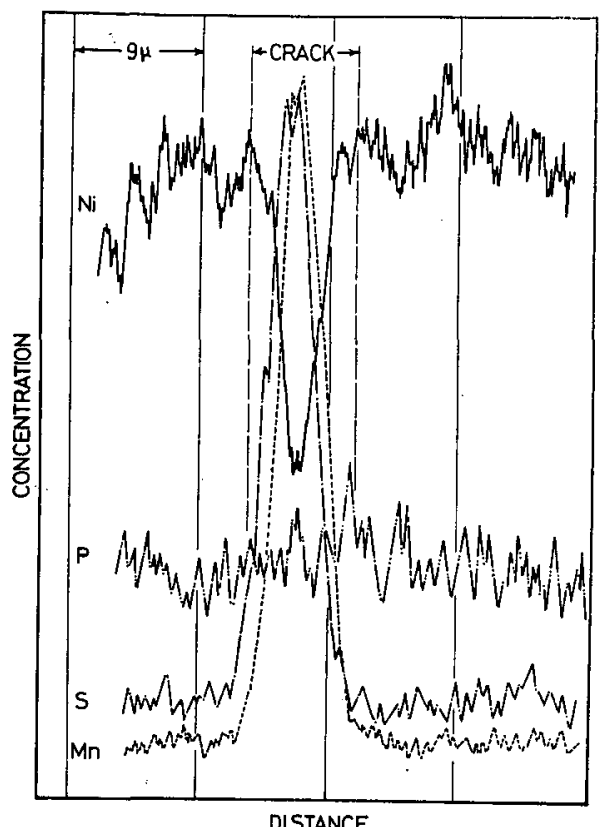

Fig. 17 Segregation of manganese and sulphur at a crack of weld metal, $\mathrm{H}(6.51 \% \mathrm{Ni})$

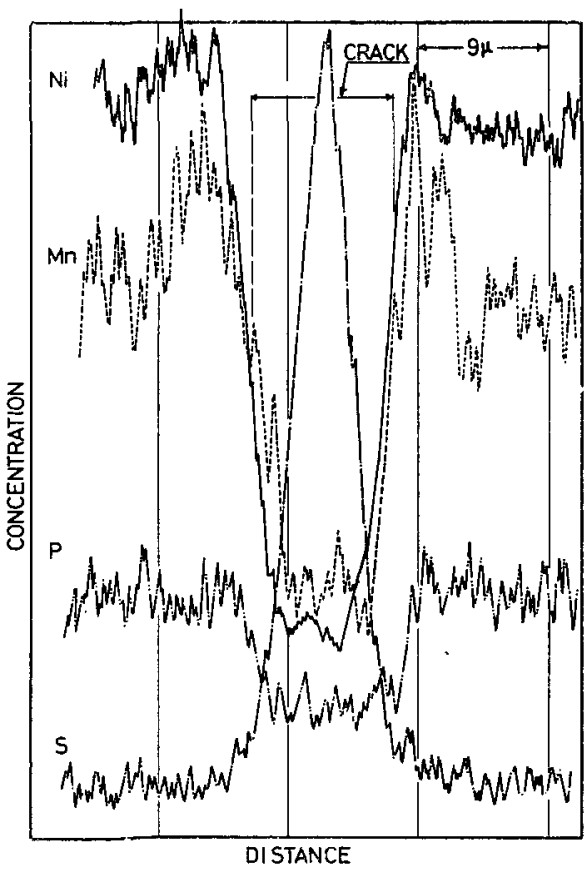

Fig. 18 Segregation of sulphur at a crack of weld metal, $\mathrm{H}(6.51 \% \mathrm{Ni})$
結果，いううは9倍の濃縮度を示した。

Fig. 17 および18は Fig. 9 に示す $r$ 相一相として凝 固する溶着鋼 $\mathrm{H}(0.90 \% \mathrm{Mn}, 0.025 \% \mathrm{P}, 0.008 \% \mathrm{~S}, 6.51$

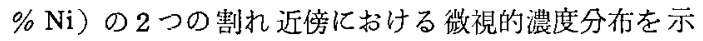
し，割れ近傍のマクロ細織は Photo. $3(\mathrm{~h})$ に示す. 何 れの割れ部分にもこれまでよりも最も高いいおうの偏析 が認められ，点分析の結果では割れた部分のい挹う濃度 は割れていない部分の20倍であった．Fig. 17 ではいお うと同时にマンガン䟴度む高く8倍であったししかし Fig. 18 ではい抢うの偏析部分でマンガンは全く逆に低 下している、なおニッケルは何れの場合に手割れ部分で 低く，りんにはほとんど变化が認められないが, Fig. 18 の場合は割れ部分でいおうと逆にやや低下している。

以上の実験結果を総括して冶金学的考察を加える。 ま ず凝固相の分類を Fe-Ni 状態図（Fig. 9) によって行 なうと。

イ） $0 \sim 3.4 \% \mathrm{Ni}, \delta$ 相，(例えば，溶着鋼 $\mathrm{A}, \mathrm{B}, \mathrm{C}$, 和よび D)

口) $3.4 \sim 6.2 \% \mathrm{Ni},(\delta+r)$ 相，（例えば，溶着錒 $\mathrm{E}, \mathbf{F}$ および G)

八) $6.2 \% \mathrm{Ni}$ 以上 $r$ 相，(例元ば，溶着鋼 $\mathrm{H}$ ) の三つにわけられる.

上述の夷験結果では（イ）の箸困では高温割れをおこ す可能性が少ないが（口）および（八）の範囲では高温 割れをおこしやすいととが認められた，との高温割れを おこす原因はX線マイクロアナライザーの結果による と，主としていおうの㾫析であり，特にりん含量の高い 場合にはりんの编析である、そこでこれらの偏析につい

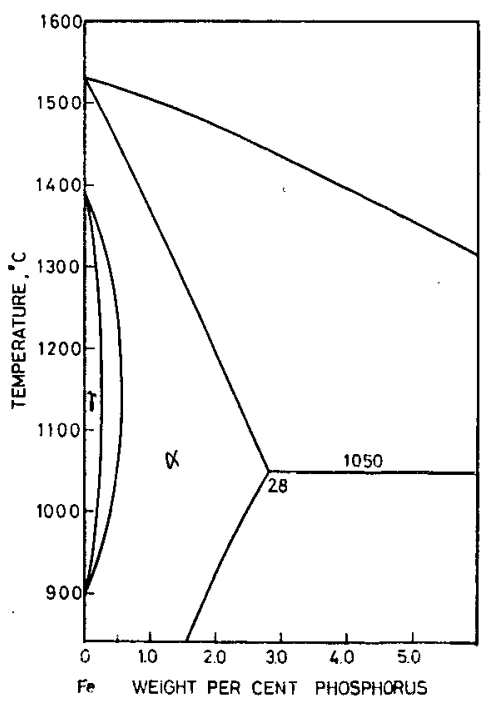

Fig. 19 Phosphor solubility of $\gamma$ and $\delta$ iron 
$\tau$ Fe-Ni (Fig. 9), Fe-S (Fig. 5) 抬よび Fe-P (Fig. 19）の二元状態図 ${ }^{2}$ により考察する.

1）の範国の二ッケル含量で $\delta$ 相一相で凝固する溶着 鋼はい抒うの固溶限が最大 $0.18 \% \mathrm{~S}\left(1365^{\circ} \mathrm{C}\right)$ であり, いおうの平均化学組成が $0.006 \sim 0.009 \%$ あれば，凝固 過程での粒界偏析の可能性は少ない，また $\delta$ 相のりん の固溶度は最大 $2.8 \%\left(1050^{\circ} \mathrm{C}\right)$ であり, $-1330^{\circ} \mathrm{C}$ では $1.0 \% \mathrm{P}$ である. したがって本実験の $0.01 \sim 0.100 \%$ り

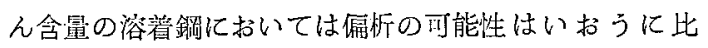
ベはるかに少ないように思われる。

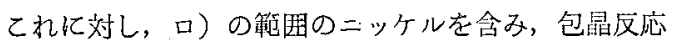
により $(\delta+\gamma)$ 相で疑固する溶着鋼では，

$$
\delta+\text { Liquid } \rightarrow r
$$

の包晶反応が行なわれる.すなわち $\delta$ 相と液相との境で

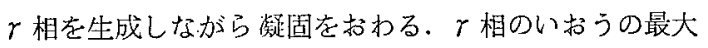
固溶度は $\delta$ 相の $1 / 3$ 以下の $0.05 \%$ あるあので, 溶融金属が

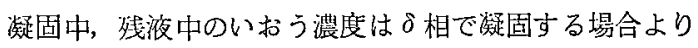
大になり，最終凝固部付近の $\gamma$ 相ではさまれる粒界のい 扣う偏析は著しくなると考えられる。実際包晶反応を伴 なって凝固した溶着鋼の最終凝固部付近の粒界古るいは 割れ部分のいおうの湛縮度は，平均化学組成を 0.006 $0.009 \%$ 程度低くしても， 5 １0倍にむ達している．乙 の過飽和のい扔うが低融点硫化物を形成して最終凝固し た結晶粒界で高温割礼を抗てすむのである、一方りんの 場合も $\delta$ 相より $r$ 相の方が固溶度はずっ上低い。しか しいおうに比べると固溶度は大きいので高温割れの原区 となるととは少ないと考えられる。もっとも高温割れを 生じた $0.10 \% \mathrm{P}$ を含有したニッケル溶着銅の場合には 割れ部分のりんの濃縮度は平均化学組成の 4 15倍に達 し, 高温割れにりんが影響する可能性む示された. しか しりんが高温割れの主因となる可能性はいおうにくらべ てずっと小さく，特別の場合と考えられる.

そして包晶反応で $r$ 相の生成量が多いほど，すなわ ち，Fig. 9 亿おいてニッケル含量が高いほど高温㓶れの 伦険性は增大する向の上思われる。

八）のニッケル含量の ケ相一相で㥆固する溶着鋼では 上述の理由によりいおうの偏析はさらに著しく高温割れ に一層敏感になるものと思われる, 溶着銅 $\mathrm{H}$ の場合, 最 終凝固粒界でのいおうの偏析が溶着鋼 $\mathrm{A} \sim \mathrm{G}$ の場合より も大きく，最終凝固部付近の粒界または高温割れ部分で いおうの浱縮度が平枃化学組成の20傍にも避しているの はこのことを証明するものであろう。

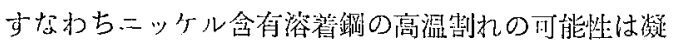
固過程の相に大きく影響され，い拈うの偏析が高温㓶れ の主原因のようである。りえの偏析の影響仿い打うに比 べればはる汃に小さい。

\section{3 ニッヶルを含有した溶着鋼の高温割れにおよ ぼす Mn/s の効果の検討}

Fig. 20 は溶着鋼の高温割れにおよぼすニッケルと $\mathrm{Mn} / \mathrm{S}$ の関係定示す，溶着銅のい找う含量は 0.006 $0.009 \%$ に押えており，マンガン含量は $0.90 \sim 1.30 \%$ な ので, $\mathrm{Mn} / \mathrm{S}$ の比は通常割れ防止にきく之言われている

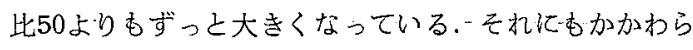
ず高温割れを発生している。それゅ必ずしも $\mathrm{Mn} / \mathrm{S}$ が高いから割れないとは言えないであるう。この原因は 溶着鎆のマンガン含量が高くなるととにより凝固過程て $\gamma$ 域を広げ，いおうの偏析を助長する可能性むあるので はないかと考えられるが，实験的にじゅう分明らかにす ることはできなかった。

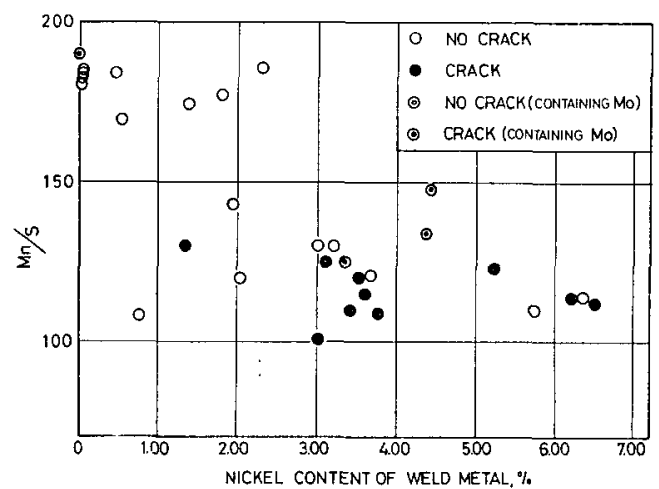

Fig. 20 Effect of nickel content and $\mathrm{Mn} / \mathrm{S}$ ratio on the hot cracking in weld metal

\section{4 ニッケル合有溶着鋼の組織}

ニッケル含量の異なる溶着鋼のマクロ組織を Photo. 3 に示す．てれらのマクロ組織を比較観察すると， $3.4 \%$ Ni 以上の溶着鍓の一つ一つのオーステナイト粒の大き さは $3.4 \% \mathrm{Ni}$ 以下の溶着銓にくらべて数倍以亡であ る.

Photo. 4 はニッケルを含有した溶着鋼 $\mathrm{F}$ に存在した 高温割れ部分を液体窒素に冷却して衝撃破断した破面を 走督型電顕で観察した一部を示す．同写真が示す破面に は樹枝状晶と考元られる滑らかな凹凹があり，ととろど ころガスの抜けた穴も認められ，乙の破面は固液界面で あったことが想像される。

\section{5. 結言}

サブマージアーク溶接による盗接鍓の微视的偏析およ

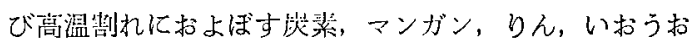
よびニッケルの影響をX 線マイクロアナライザーを使っ て調べた結果, 次のことがわかった。

1）溶接鋼の湠素會骨が $0.10 \%$ 以上場合， $0.10 \% \mathrm{C}$ 


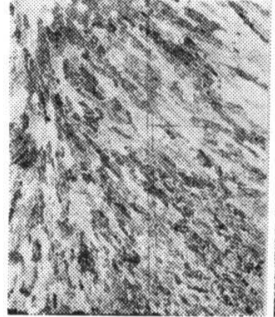

a) $\quad 0.03 \% \mathrm{Ni}$

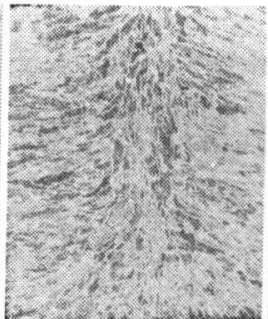

b) $0.55 \% \mathrm{Ni}$

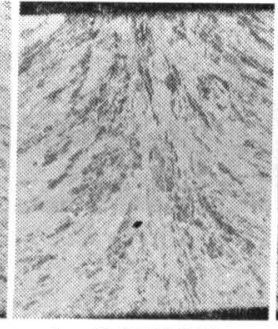

c) $2.31 \% \mathrm{Ni}$

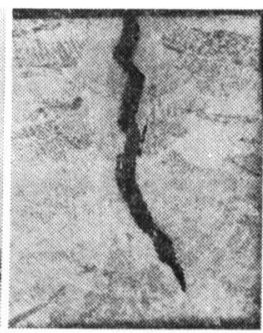

g) $5.21 \% \mathrm{Ni}$

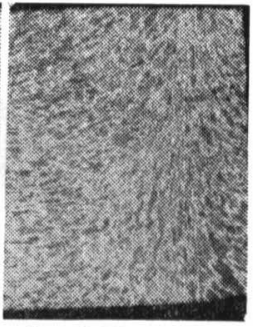

d) $3.02 \% \mathrm{Ni}$

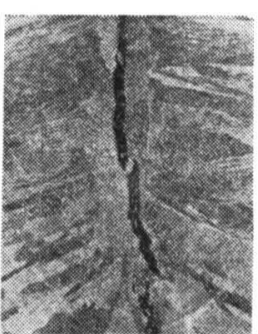

h) $\quad 6.51 \% \mathrm{Ni}$

e) $3.42 \% \mathrm{Ni}$

f) $4.36 \% \mathrm{Ni}$

Photo. 3 Effect of nickel content on macro structures of metals

$\times 10 \times 1 / 2$

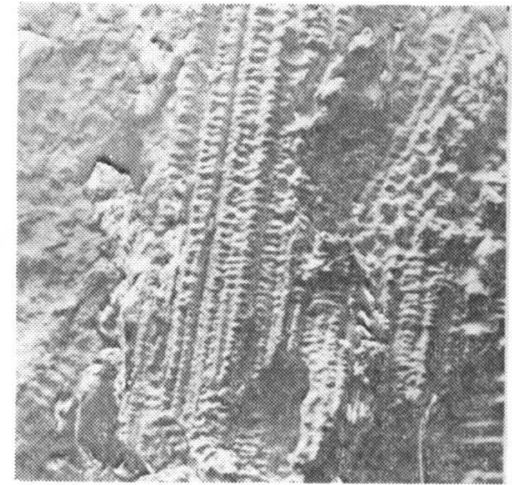

a) $50 \times 1 / 2$

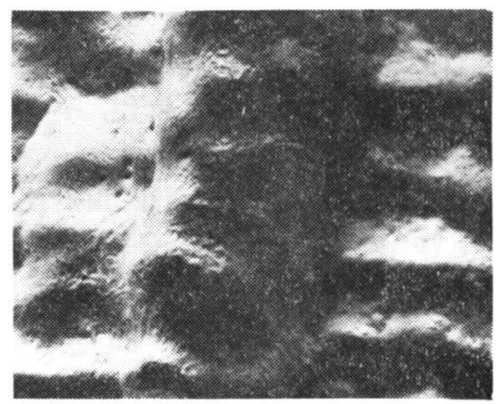

c) $\times 600 \times 1 / 2$

以下の溶按辋にくらべて，い书うの微視的偏析が いちじるしく、マンガンもいおうに対応して濃度 変化を示した.

2) ニッケルを含有した溶接銅の微視的偏析あるいは 高温割れは $\mathrm{Fe}-\mathrm{Ni}$ 系状態図の初晶として晶出す る相の影響死大き受け，包晶反応に上る いおうおよびりんの偏析を助長する。

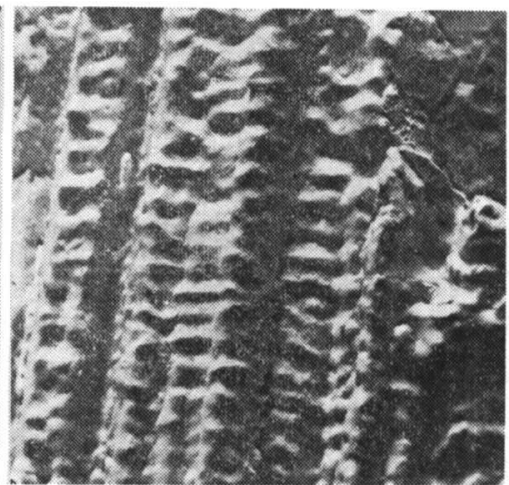

b) $\times 100 \times 1 / 2$

Photo. 4 Electron fractograph of hot crack surface in weld metal, $\mathrm{F}(4.36 \% \mathrm{Ni})$

3 ）溶接銅の高温割れの主因はいおうう偏析であり, りんの影響はいおうに比べはるかに小さい。

\section{参考文 献}

1) 関口, 益本, 今井：低温用銅材の $\mathrm{CO}_{2}-\mathrm{O}_{2}$ アーク溶接について (第 1 報) 一溶接銅の高温割れ- 溶接学会誌 35 (1966) No. 10, p. $77-81$

2) Max Hansen : Constitution of Binary Alloys, second edition MCGRAWHILL BOOK COMPANY. 